\title{
The Factors Affecting Corporate Income Tax Non-Compliance: A Case Study in Vietnam
}

\author{
Loan Thi NGUYEN', Anh Hong Viet NGUYEN², Hac Dinh LE ${ }^{3}$, Anh Hoang LE ${ }^{4}$, Tu Tuan Vu TRUONG
}

Received: June 02, 2020 Revised: June 28, 2020 Accepted: July 11, 2020

\begin{abstract}
In many countries, the Government enacts tax laws in order to manage tax collection and regulate the macro-economy. According to Noor, Jamaludin, Omar, and Aziz (2013), tax non-compliance is a growing concern because of its negative effects on the state budget. The main objectives of this article are to identify the factors affecting corporate income tax non-compliance of enterprises in Ho Chi Minh City in accordance with the current situation of Vietnamese tax administration. We use several research methods, including the exploitation of information and practical experiences from both taxpayers and tax authorities; with Probit regression model on a sample of 187 enterprises that have been inspected or examined by tax authorities in Vietnam during the period from 2013 to 2017.The article identified eight factors affecting corporate income tax (CIT) non-compliance: (1) working capital/total assets; (2) revenue/total assets; (3) total debt/total assets; (4) loss in the previous year; (5) receivables/revenue; (6) the size of enterprises; (7) tax administrative penalties/tax payable; and (8) business field. In particular, the tax non-compliance was studied as a violation of Vietnamese tax laws by enterprises declaring an insufficient amount of CIT payable to the State budget.
\end{abstract}

Keywords: Corporate Income Tax,Tax Non-Compliance, Enterprise, Vietnamese Tax Law

JEL Classification Code: H25, G30, G38, M10

\section{Introduction}

Tax is not a new notion. In many countries, the Government has always enacted tax laws to manage tax collection and regulate the macro-economy (Nguyen, 2019). According to Noor, Jamaludin, Omar, and Aziz (2013); Oh and $\mathrm{Ki}$ (2020), tax non-compliance has been a growing concern because of its negative effects on the state budget.

${ }^{1}$ First Author. Lecturer, Faculty of Accounting and Auditing, Banking University of Ho Chi Minh City, Vietnam. Email: Ioannt@buh.edu.vn ${ }^{2}$ Tax Staff, Binh Thanh District Tax Department, Ho Chi Minh City, Vietnam. Email: nvhanh.hcm@gdt.gov.vn

${ }^{3}$ Lecturer, Faculty of Postgraduate Education, Banking University of Ho Chi Minh City, Vietnam. Email: hacld@buh.edu.vn

${ }^{4}$ Corresponding Author. Researcher, Institute for Research Science and Banking Technology, Banking University of Ho Chi Minh City, Vietnam [Postal Address: 39 Ham Nghi Street, District 1, Ho Chi Minh City, 700000, Vietnam] Email: anhlh_vnc@buh.edu.vn

${ }^{5}$ Banking Officer, Military Bank, Ho Chi Minh City, Vietnam. Email: tutvt.ld@mbbank.com.vn

() Copyright: The Author(s)

This is an Open Access article distributed under the terms of the Creative Commons Attribution Non-Commercial License (http://Creativecommons.org/licenses/by-nc/4.0/) which permits unrestricted noncommercial use, distribution, and reproduction in any medium, provided the original work is properly cited.
Since the 1990s, Kamdar (1997) studied the impact of factors affecting non-tax compliance in the United States during the period from 1961 to 1987 . According to the US Federal Reserve, the amount of tax discrepancy identified during the business tax declaration process was estimated at USD450 billion in the tax year 2006. Besides, the amount collected through recovery measures was USD385 billion, and the percentage of compliant taxpayers has been very low over the past three decades.

In Vietnam, according to the Ministry of Finance (2016), corporate income tax has always accounted for a large proportion of the structure of state budget revenue during the long period from 2001 to 2015 . Article 6, Article 7, Article 8 and Article 9 of the Vietnamese Law on Tax Administration No. 78/2006/QH11 dated November 29, 2006, regulated the rights and obligations of taxpayers and the duties of tax authorities. Accordingly, the enterprises have to declare their tax obligations annually to tax administrators, and the tax officials are responsible for supporting and inspecting the companies' declared tax amount. However, the statistic of Vietnamese institutions in 2016 showed that 91,419 enterprises violating tax law had to pay 17.285 billion dongs and refunded 1,400 billion dongs for the state budget, 
reducing the tax deduction of 79 billion dongs (Ministry of Finance, 2016). In 2017, the tax amount collected from examinations of the tax administrations increased to 17,960 billion dongs. Thus, it can be seen that not many enterprises in Vietnam complied with the Vietnamese tax law.

Yalama and Gumus (2013); Abdixhiku (2013); Awan and Hanna (2014); Yahyapour, Boroujeni, and Kheradyar (2015) studied the factors affecting tax non-compliance through the survey data of tax return information from taxpayers. Other studies such as Mills (1996); Joulfaian (2000); Hanlon, Mills, and Slemrod (2005); Zainal, Hasseldine, and Paton (2010); Lisowsky (2010); Noor, Aziz, and Mastuki (2012); Noor, Jamaludin, Omar, and Aziz (2013); Yusof, Ling, and Wah (2014) presented an empirical research model on factors affecting tax non-compliance of enterprises based on financial statement data. Besides, GIZ Sector Program Public Finance (2010); Le and Nguyen (2013); Nguyen, Pham, Le, Truong, and Tran (2019); Salehi, Khazaei, and Tarighi (2019)examined and summarized the causes of tax fraud through the analysis of the situation and experiences from previous studies.

Therefore, the main objectives of this article are to identify the factors affecting corporate income tax noncompliance of enterprises in Ho Chi Minh City in accordance with the current situation of Vietnamese tax administration base on the data using for tax declaration in order to suggest some solutions for tax administrations to reduce the impact of tax non-compliance. The paper consists of five sections. Following this introductory section, Section 2 provides an overview of the previous studies. Section 3 describes our research methodology. The results are presented in Section 4. Conclusions and corresponding solutions for tax management are discussed in the Section 5.

\section{Literature Review}

\subsection{The Definition of Corporate Income Tax Non- Compliance}

Nguyen and Nguyen (2012) explained that the traditional view of tax administration was mainly based on the assumption that most businesses do not comply with tax obligations. According to Alm (1991), tax compliance was known as the accurate declaration of income and expenses regulated by the Tax Law.

The BISEP model (Organization for Economic Cooperation and Development, 2004) introduced the concept of tax non-compliance depending on the level of compliance costs and pressure. According to Alabede, Ariffin, and Idris (2011), tax non-compliance appeared in many different forms including tax fraud, defined as tax non-compliance behaviors such as inaccurate tax declaration, failure to pay tax,and not to comply with the regulations of tax law.
According to Singh (2003), non-compliance with corporate income tax occurs when violations of the tax law occur, such as hiding revenue and claiming cost. Tan and Sawyer (2003) explained that the corporate income tax compliance was the accurate declaration of income and expenses following tax law so that the companies that failed to report these two elements accurately or do not carry out tax obligations were non-compliant taxpayers.

According to Article 103 of the Vietnamese Tax Administration Law No. 78/2006/QH11 dated November 29, 2006, violations of tax law include: (1) violation of procedures, (2) delaying tax payment, (3) false declaration of payable tax amounts, and (4) tax evasion. However, a number of studies have researched corporate income tax non-compliance as a false declaration of income reflecting the corporate income tax obligation, which is the main behavior affecting the State budget. The corporate income tax non-compliance in this study is defined as the violations of Vietnamese tax law to minimize corporate income tax amount, which is reflected in the figures on financial statements of companies.

\subsection{The Theory of Tax Non-Compliance}

Economic Deterrence Model: Becker (1968) has developed principles of economic deterrence model in the 1960s. This research analyzed illegal behaviors using one economic framework. Becker (1968) proposed a narrow argument that the probability of detection and penalties would affect taxpayers' compliance. By the 1970s, based on the Utility Theory, Allingham and Sandmo (1972) argued that, in order to optimize the benefits, the taxpayers would think carefully to make compliance decisions in their tax reports, whereas tax fraud might appear if the financial benefit is lower than the financial cost. Therefore, the economic deterrence model has been developed with the concept that the deterrence affects taxpayers' compliance behavior (Devos, 2014). Following that, the economic deterrence model appeared in several versions, but in general, the researchers concluded that the determinants of financial cost might have influences on tax compliance such as the complexity of tax structure, tax rate, the probability of detecting violations, income level, and penalty structure. However, there were not many pieces of evidence proving the correctness of some predictions from the economic deterrence model (Devos, 2014). After that, another method emerged to study tax compliance - the fiscal and social psychology models.

Fiscal and Social Psychology Models: The approach of fiscal and social psychology models is to examine the human factors influencing tax compliance behaviors. Factors affecting tax compliance identified from these models' point of view changed from social norms and personal norm to 
awareness of taxpayers (Devos, 2014). One of the earliest studies on tax evasion, which explored a "tax mentality" concept was presented by Schmolders (1959). Therefore, if taxpayers have a positive attitude towards their tax obligations and behaviors of tax officials, they are willing to pay taxes. Kinsey (1986) explained that the concept of "willingness to cooperate" might relate to compliance. Thus, taxpayers who are very cooperative in working with tax officials might be compliant taxpayers. Spicer (1974) mentioned the inequity between tax paid on goods and public services provided by the Government. Vogel (1974); Song and Yarborough (1978) examined the effect of ethical values on taxpayers' compliance and stated that both the fairness and the morale were the determinants relating to compliance behavior. Lewis (1982) also conducted psychological research about tax to examine taxpayers' attitudes and perceptions in order to understand their compliant behaviors and how tax evasion is. During the 1990s and early 2000s, other variables in the fiscal and social psychology models have not appeared in the economic deterrence model (Devos, 2014). In conclusion, there were several theoretical backgrounds of tax compliance throughout the years of research such as the economic deterrence model and fiscal and social psychology models, but they were still controversial.

Fraud Triangle's Theory of Cressey (1953): According to Alabede, Ariffin, and Idris (2011), the definition of tax non-compliance included the concept of tax fraud so that the theory of fraud behavior was mentioned to analyze and find out the research framework for this study. The Fraud Triangle's Theory of Cressey (1953) presented that there are three factors contributing to carrying out the illegal violations of people. They are: (1) pressure/motivation, (2) opportunity, and (3) rationalization/attitude.

+ Pressure/motivation: The reason for carrying out violations is the pressure. The pressure may be financial situations, which increase the motivation for committing fraud.

+ Opportunity: This factor also shows the measure of committing violations. Once the pressures exist, if there were any opportunities, fraud will be committed. This might be related to the gaps in the regulations of the tax system.

+ Rationalization/attitude: Cressey (1953) explained that the personality of each individual might be the primary factor to conduct fraudulent actions. It is said that some people who have a chance and may be under pressure are willing to commit fraud. Cressey (1953) also said that this is a natural reaction of people for the first time doing things against their conscience and morals, but in the next times they commit fraud, they will feel more easily accepted. Therefore, the influence of attitude on cheating behavior depends on the opinion and judgment of people. The Fraud Triangle's Theory of Cressey (1953) has been used to explain many violations and applied to study frauds in many fields.
Briefly, the Fraud Triangle's Theory of Cressey (1953) was used in this study to conduct the framework for analyzing the factors affecting corporate income tax non-compliance of businesses in the environment of Vietnamese Tax Law. The authors explained that these factors of the Fraud Triangle were mentioned in many concepts in the Economic Deterrence Model, the Fiscal and Social Psychology Models and the BISEP model (Organization for Economic Cooperation and Development, 2004; Devos, 2014). Hence, the implications of tax non-compliance conducted in this article are that there might be a high risk of tax violations when the pressure is high, the compliant attitude is low and there are several opportunities to evade to carry out tax obligations.

\subsection{The Factors Affecting Tax Non-Compliance}

Public service quality: People generally depend heavily on certain types of services or consumption benefits because of the tax paid. If public goods and services that meet the requirements of the individual can not be provided by the government, taxpayers are no longer willing to pay taxes. The lower the quality, the less they pay tax (Pashev, 2005; Lieberman, 2002; Brautigam, Odd-Helge, \& Moore, 2008; Giz Sector Programme Public Finance, 2010).

Level of corruption: The lack of transparency in tax revenue and public spending has an even more negative impact on tax evasion (Kirchler, Muehlbacher, Kastlunger, and Wahl, 2007). Taxpayers may collude with tax officials if the amount paid for bribery is lower than the payable tax amount. Therefore, the higher the level of corruption is, the more the tax non-compliant enterprises are (Giz Sector Programme Public Finance, 2010).

Penalties for tax offenses: The legal framework for penalties also significantly affects the level of tax compliance (Fishlow and Friedman, 1994). From the researchers' point of view, the probability of fraud detection and the penalty were also confirmed to have a negative effect on tax noncompliance. Taxpayers may consider whether compliance or non-compliance will be more beneficial (Giz Sector Programme Public Finance, 2010).

Tax administration: According to Giz Sector Programme Public Finance (2010), many developing countries faced difficulties in tax management, which affected the function and role of the tax department in the economy. The ability of the tax department to manage cash flow or control transactions of enterprises ineffectively would affect tax non-compliance (Giz Sector Programme Public Finance, 2010). The complicated tax system might influence on tax non-compliance if there is not effective management of tax collection (Mo, 2003).

Tax legislation system and equity perspective: Some studies suggested that high tax rates increased tax burden on the taxpayers' income (Alligham \& Sandmo, 1972; Chipeta, 
2002). The Organization for Economic Cooperation and Development (2004) argued that tax laws in many countries were still inaccurate and unclear which created opportunities for companies to commit tax fraud. Therefore, the weakness in the legal regulations on tax administration would affect the compliance of taxpayers. If the tax law has many loopholes, there might be more non-compliant taxpayers.

Compliance cost: Compliance cost is an issue that cannot be ignored when analyzing the factors affecting tax non-compliance. Businesses that incur more and more costs during production will tend to reduce their tax pressure by avoiding tax obligations. Therefore, if the compliance cost grows up, the probability of enterprises committing tax fraud might increase (Giz Sector Programme Public Finance, 2010).

\subsection{Review of Related Studies}

Giz Sector Programme Public Finance (2010), Abdixhiku (2013), Sapiei, Kasipillai, and Eze (2014), Awan and Hannan (2014), Yahyapour, Boroujeni, and Kheradyar (2015) analyzed the factors affecting tax fraud, in which the factors given in the model played roles as several causes of tax evasion. In addition, a number of studies have found a link between tax non-compliance with the information in financial statements and tax officials can make assessments of corporate income tax non-compliance based on the financial statements. They are Lisowsky (2010); Noor, Aziz, and Mastuki (2012); Noor, Jamaludin, Omar, and Aziz (2013); Yusof, Ling, and Wah (2014). Mills (1996) investigated corporate income tax compliance and financial performance. He said that tax officials found out the lack of corporate income tax payment caused by the differences between book profit and taxable income declared in financial statements. The incorrect information in financial statements will lead to unsuitable tax reports and lead to corporate income tax noncompliance (Frank, Lynch, \& Rego, 2009).

The related studies in Vietnam mainly mentioned and analyzed the situation and experience in identifying businesses' non-compliance behaviors of tax officials in order to propose solutions. The research by Le and Nguyen (2013) presented specific violations of tax fraud by enterprises, so that tax departments have to design solutions to limit this situation. In particular, a study by $\mathrm{Vu}$ (2009) concluded that the indicators on the financial statements were related to the corporate income tax compliance, which was shown by the difference between the self-declared corporate income tax and the amount from tax examinations. Besides, a number of factors affecting the tax compliance of enterprises in the study of Nguyen and Nguyen (2012); Bui (2017) suggested that it was necessary to consider the comments of taxpayers and tax officials on the situation of tax non-compliance. The applied research methods include analytical techniques, synthesis, and survey. A number of studies have used quantitative methods such as multiple regressions, exploratory factor analysis (EFA), Logit regression to carry out research. In this study, we will demonstrate the relationship between the factors affecting corporate income tax non-compliance with the combined method through the inheritance of previous studies and the reference from the experience of tax departments.

\section{Research Methodology}

\subsection{Research Methods}

The authors conducted the study with the combined methods through two specific stages as follows:

Stage 1: Synthesizing the theoretical basis combined with results of group discussions and face-to-face discussions with experts from tax departments and the enterprises inspected by tax officials in order to propose the model of factors affecting corporate income tax non-compliance.

Stage 2: After generating the proposed model from the previous phase, the authors carried out the Probit regression with a table dataset including 935 observations (187 enterprises that had been inspected through tax examinations from 2013 to 2017) in order to verify the factors affecting corporate income tax non-compliance. The quantitative regression methods have been implemented in many previous studies such as Lisowsky (2010); Noor, Aziz, and Mastuki (2012); Noor, Jamaludin, Omar, and Aziz (2013); Yusof, Ling, and Wah (2014).

\subsection{Research Model}

The method used for sampling during group discussions and face-to-face discussions is the theoretical sampling method. The number of samples was determined based on the perspective of Gummesson in Nguyen (2011). Therefore, the number of samples was identified at the level of information collected, which did not have any difference from the previous. Then, the authors continued to select an additional sample to confirm the saturation point; if there were no new information, the sampling process would stop.

The combined results of group discussions and face-toface discussions process showed that there were 11 factors explored from 20 situations of enterprises and 15 experts of tax departments. Therefore, in order to select the factors for the proposed model the authors chose the elements that were supplied by both the enterprise and the experts from tax departments and eliminate factors with low approval rates. The study presented the factors explored by businesses and tax officials and arranged them based on the descending order of the rate of approval (Figure 1): 


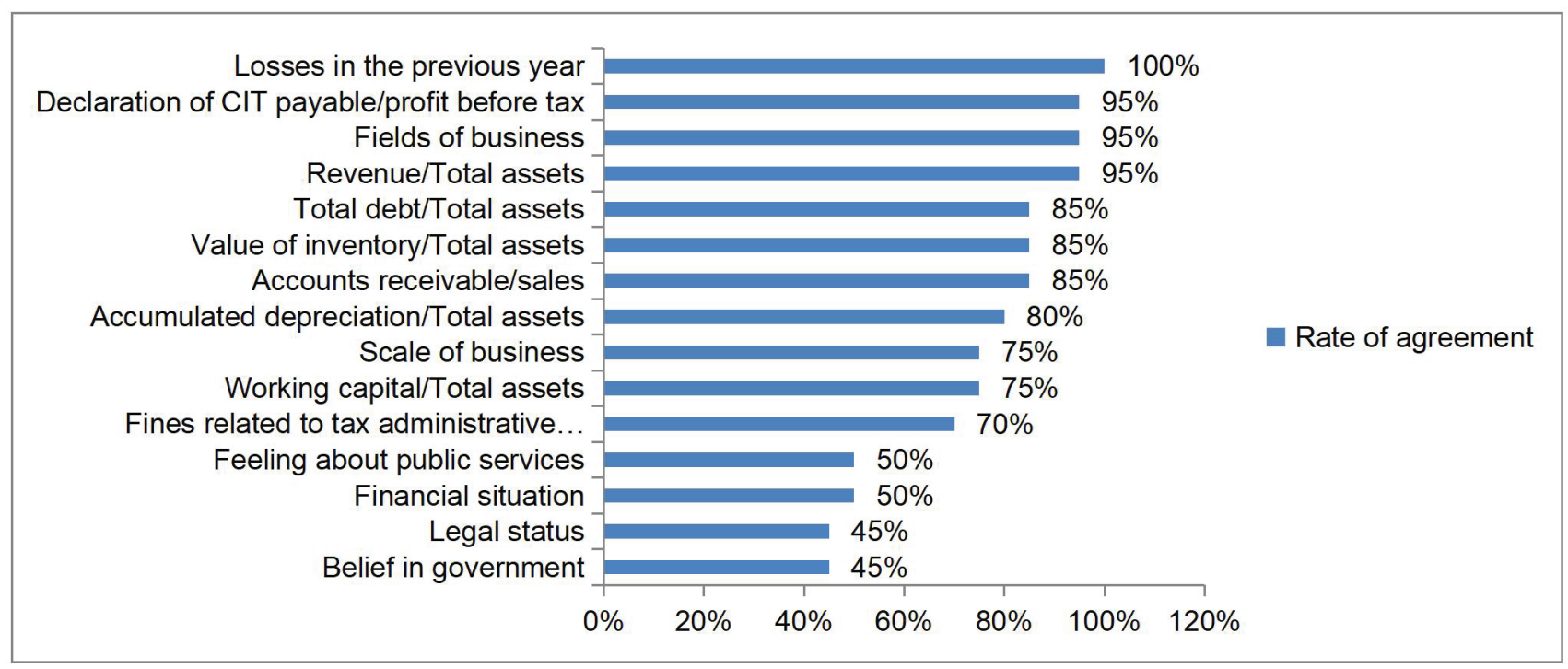

Figure 1: Factors affecting corporate income tax non-compliance given during discussions

Factors included in the research model must have a high rate of approval (over $50 \%$ of the sample participating in the discussions). Hence, the article removed four factors: (1) legal status, (2) belief in the Government, (3) feeling about public services, and (4) financial situation of enterprises. The relationships between each factor and corporate income tax non-compliance were identified given during the discussions. In conclusion, the discussion methodology has identified 11 factors that affect corporate income tax non-compliance, as represented in Table 1:
We designed a quantitative research model illustrated by Figure 2 and presented as a Probit regression equation, as following:

$$
\begin{aligned}
P_{i}= & \operatorname{Pr}(Y=1 \mid X)=\operatorname{Pr}\left(I_{i}^{*} \leq I_{i}\right)=\operatorname{Pr}\left(Z_{i} \leq B X\right)=\mathrm{F}(B X) \\
P_{\mathrm{i}}= & \operatorname{Pr}\left(n c t_{i t}=1 \mid X_{i}\right)=\beta_{0}+\beta_{1} w c_{\mathrm{it}}+\beta_{2} \text { sale }_{\mathrm{it}}+\beta_{3} \\
& \operatorname{debt}_{\mathrm{it}}+\beta_{4} \text { loss }_{\mathrm{it}}+\beta_{5} \text { inv }_{\mathrm{it}}+\beta_{6} \text { ar }_{\mathrm{it}}+\beta_{7} \text { depr }_{\mathrm{it}}+ \\
& \beta_{8} \text { etr }_{\mathrm{it}}+\beta_{9} \text { size }_{\mathrm{it}}+\beta_{10} \text { pen }_{\mathrm{it}-1}+\beta_{11} \text { field }_{\mathrm{it}}+\mathrm{u}_{\mathrm{it}}
\end{aligned}
$$

Table 1: Results of discussion on the factors affecting corporate income tax non-compliance

\begin{tabular}{|c|l|c|c|c|}
\hline \multirow{2}{*}{ Code } & \multicolumn{1}{|c|}{ Factors } & $\begin{array}{c}\text { Number of people } \\
\text { giving comments }\end{array}$ & $\begin{array}{c}\text { Rate of } \\
\text { agreement }\end{array}$ & Effect Trend \\
\cline { 3 - 5 } & & 19 & $95 \%$ & $(+) /(-)$ \\
\hline 1 & Declaration of CIT payable/profit before tax & 19 & $95 \%$ & $(-)$ \\
\hline 2 & Fields of business & 15 & $75 \%$ & $(-)$ \\
\hline 3 & Scale of business & 14 & $70 \%$ & $(-)$ \\
\hline 4 & $\begin{array}{l}\text { Fines related to tax administrative violations/tax } \\
\text { amounts payable in the period }\end{array}$ & 20 & $100 \%$ & $(+)$ \\
\hline 5 & Losses in the previous year & 15 & $75 \%$ & $(-)$ \\
\hline 6 & Working capital/Total assets & 19 & $95 \%$ & $(+)$ \\
\hline 7 & Revenue/Total assets & 17 & $85 \%$ & $(+)$ \\
\hline 8 & Total debt/Total assets & 17 & $85 \%$ & $(+)$ \\
\hline 9 & Value of inventory/Total assets & 17 & $85 \%$ & $(-)$ \\
\hline 10 & Accounts receivable/sales & 16 & \multicolumn{2}{|c|}{} \\
\hline 11 & Accumulated depreciation/Total assets & $80 \%$ & $(+)$ \\
\hline
\end{tabular}




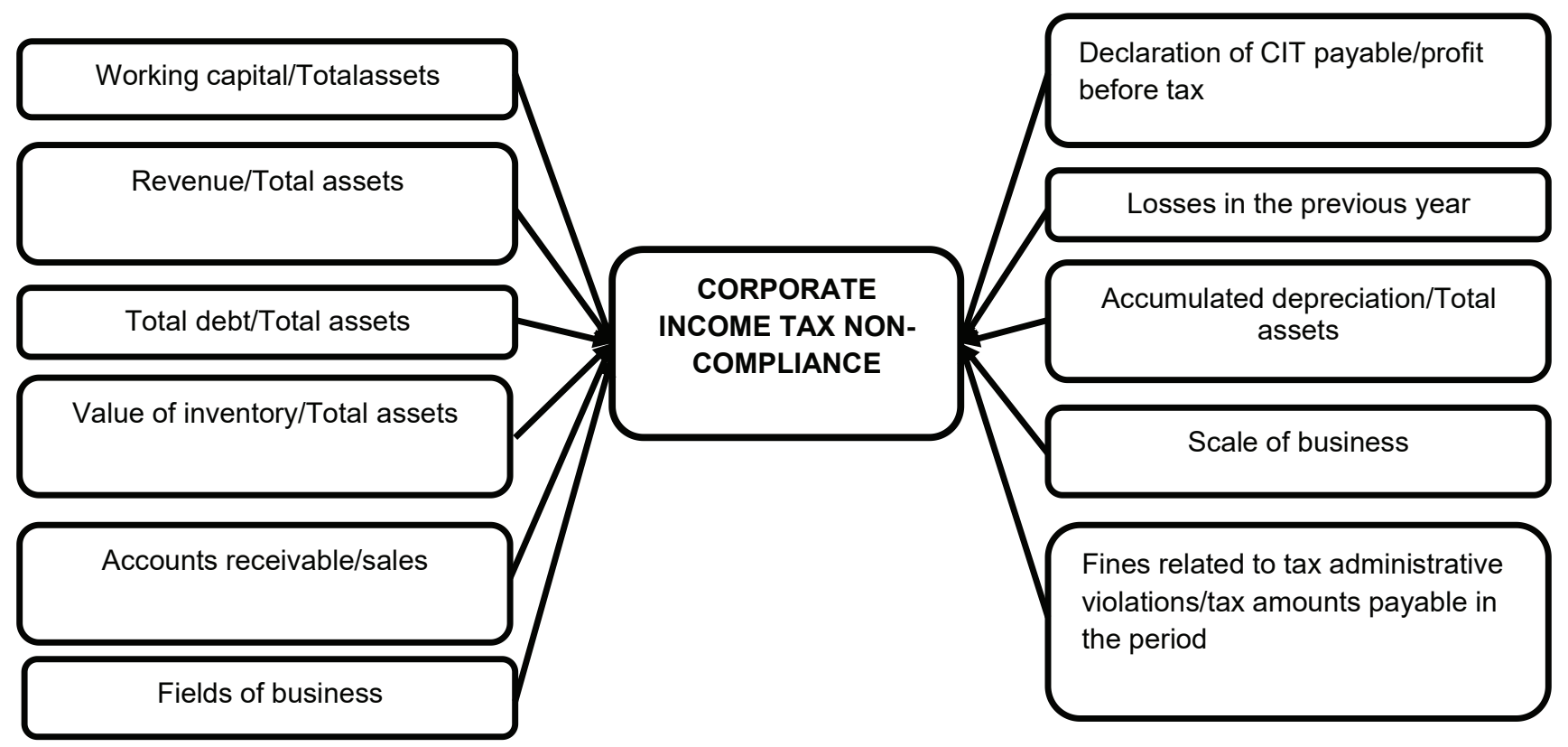

Figure 2: The proposed research model

- Corporate income tax non-compliance (nct): Inheriting previous research by Noor, Aziz, and Mastuki (2012), Lisowsky (2010), the dependent variable measures the ability of businesses to comply with tax. Corporate income tax compliance enterprises were defined as the cases in which businesses had no differences in taxable income between before and after taxation is inspected (the difference is $0 \%$ ). The other cases are classified as corporate income tax non-compliance:

$$
\begin{aligned}
& \text { GAP }=\frac{\left|\begin{array}{l}
\text { Taxable income before tax inspection } \\
- \text { Taxable income after tax inspection }
\end{array}\right|}{\text { Taxable income after tax inspection }} \\
& \text { nct }=0 \text { if GAP }=0 \%(\text { tax compliant enterprise }) \\
& \text { nct }=1 \text { if GAP }>0 \%(\text { tax non-compliant enterprise })
\end{aligned}
$$

- Working capital/Total assets: If enterprises have a high ratio of working capital to total assets, they are in a quite stable financial situation (Noor, Aziz, \& Mastuki, 2012). Spathis (2002) found that a low working capital-to-total asset ratio was associated with false financial statements on Greek listed companies.Yusof, Ling, and Wah (2014) suggested that enterprises with low solvency would find out a measure to reduce costs and were not willing to pay tax.

$$
\begin{aligned}
\mathrm{WC}= & (\text { Money }+ \text { Short-term investment }+ \text { Short- } \\
& \text { term receivable }) / \text { Total assets }
\end{aligned}
$$

H1: The lower the working capital/total assets, the greater the chance of corporate income tax non-compliance

- Revenue/Total assets: Noor, Aziz, and Mastuki (2012) argued that the high ratio of revenue-to-total assets might make managers protect the income generated so they declared a lot of illegal expenses in order to reduce taxable income during the period. Murray (1995) provided strong evidence that a company generating high revenue would be more likely to fail to declare tax. In addition, Persons (1995), as well as Skousen, Smith, and Wright (2009), suggested that the ratio of revenue-to-total assets showed the financial stability of enterprises. Therefore, this ratio may have a negative relationship with corporate income tax non-compliance. However, the results of discussions showed that the higher this factor, the bigger the number of enterprises did not comply with corporate income tax law. Thus, hypothesis 2 was set as follows:

Sale $=($ Total Revenue/Total Assets $)$

H2: The more revenue generated from the total investment in a business, the greater the chance of CIT non-compliance 
- Total debt/Total assets (debt): This ratio represents the financial leverage of enterprises. Noor, Aziz, and Mastuki (2012), Lisowsky (2010) and Yusof, Ling, and Wah (2014) suggested that there was a relationship between financial leverage and tax noncompliance. If businesses had high financial leverage, they might get benefits from a tax shield due to high interest expenses to minimize the tax payable amount.

$$
\text { Debt }=(\text { Total Debt } / \text { Total Assets }) \text {. }
$$

H3: The more debt a business has, the more likely it does not comply with CIT obligation

- Losses in the previous year (loss): Experience in tax inspection of enterprises shows that enterprises often declare losses for many years to avoid paying corporate income tax. Lou and Wang (2009) mentioned that losses would create pressure in the declaration of information related to business activities, which leads to tax non-compliance behaviors. Duong (2011) said that financial status was also associated with the fraud. Therefore, in order to test the discovered factors confirmed by the discussion method, we put a variable of loss in the previous year in the model.

H4: Enterprises with losses the previous year are more likely to be non-compliant with CIT

- Value of inventory/Total assets (inv):Loebbecke, Eining, and Willingham (1989); Noor, Aziz, and Mastuki (2012); Summers and Sweeney (1998); Skousen, Smith, and Wright (2009) founded the correlation between inventory ratio and noncompliance with corporate income tax. Thus, it is reasonable to expect companies with low inventory value to inflate this value to lower taxes.

inv $=$ Value of inventory/Total assets

H5: There was a positive relationship between the ratio of inventory-to-total assets and CIT non-compliance

- Accounts receivable/sales (ar):Noor, Aziz, and Mastuki (2012) suggested that the higher the ratio of receivables to sales, the larger the frequency of tax evasion. Summers and Sweeney (1998), Schilit (2002) suggested that there is a link between the declaration of revenue and the receivables of businesses.

ar $=$ Account Receivable/Total Revenue
H6: The more receivables a company has, the more likely they are to fail to comply with CIT

- Accumulated depreciation/Total assets (depr): Depreciation cost is a deductible expense when measuring taxable income regarded as a corporate non-debt-tax shield. Mills (1996) argued that the net depreciation ratio to total assets related to company tax non-compliance. In Vietnam, the results of the discussions showed that overstating corporate depreciation expenses was one of the tax violations.

$$
\text { depr }=\text { Accumulated depreciation/Total assets }
$$

H7: There was a positive relationship between the ratio of accumulated depreciation to total assets and CIT noncompliance

- Declaration of CIT payable/profit before tax (etr): According to Noor, Aziz, and Mastuki (2012), the tax rate determined the ability of enterprises to control the tax burden. Previous studies have provided some evidence of the relationship between tax rates and tax compliance behavior. Rice (1992), Joulfaian (2000) and Zainal Abidin et al. (2010) suggested that tax declaration rates are negatively related to corporate income tax noncompliance. Yusof, Ling, and Wah (2014); Noor, Aziz, and Mastuki (2012) suggested that there was an inverse relationship between tax rates and corporate income tax non-compliance.

$$
\text { etr }=\text { declared CIT/profit before tax }
$$

H8: The higher the effective tax rate, the less likely the enterprise is to fail to comply with CIT

- The scale of business(size): Rice (1992);Hanlon, Mills, and Slemrod (2005) proposed that the size of enterprises was expressed by the value of Total Assets or Revenue in the period, and they found out a positive relationship between firm size and tax noncompliance. In addition, Joulfaian (2000), Yusof, Ling, and Wah (2014) suggested that the scale of business was negatively related to corporate income tax non-compliance.

$$
\text { size }=\log (\text { Total Assets }) .
$$

H9: The smaller the size of the enterprise, the more likely it is not to comply with high CIT 
- Fines related to tax administrative violations/tax amounts payable in the period (pen):Allingham and Sandmo (1972) indicated a positive relationship between fines and declared income. Some studies found no correlation between such factors as Kamdar (1997) and Braithwaite (2009). Yusof, Ling, and Wah (2014) also integrated this aspect into the analysis of tax non-compliance factors.

pen $=$ tax fines/tax amount payable in the period

H10: Enterprises with a lower ratio of tax fines to tax amount payable in the period are more likely to fail to comply with high CIT

- Fields of business (field): Rice (1992), Hanlon, Mills, and Slemrod (2005), Yusof, Ling, and Wah (2014) identified enterprises that would have fraudulent techniques exploited from several characteristics of different business sectors. Chan and Mo (2000) confirmed that businesses in the service sector might not comply with tax law. Meanwhile, Rice (1992) realized that service firms were more tax compliant than others. The authors chose two fields of business related to several behaviors of tax evasion in order to set the classification variable with the remaining field. They were construction (industry code F), and accommodation and catering services (industry code I). The article sets the field variable to be a classification variable that receives a value of 1,2,3. With 1: the company belongs to the reference field; 2 : construction industry companies; 3 : accommodation and catering companies. We added two dummy variables into the regression model, namely, as field2 and field3.

H11: Business lines impact the corporate income tax non-compliance ability of companies.

Table 2: Hypothesis and expectation of the sign of independent variable

\begin{tabular}{|c|c|c|c|c|}
\hline Code & Name of variables & Symbol & Hypothesis & $\begin{array}{l}\text { Expectation } \\
\text { of the sign }\end{array}$ \\
\hline 1 & $\begin{array}{l}\text { Working capital/Total } \\
\text { assets }\end{array}$ & wC & $\begin{array}{l}\text { H1: The lower the working capital/total assets, the greater } \\
\text { chance of corporate income tax non-compliance. }\end{array}$ & $(-)$ \\
\hline 2 & Revenue/Total assets & sale & $\begin{array}{l}\mathrm{H} 2 \text { : The more revenue generated from the total investment in } \\
\text { a business, the greater chance of CIT non-compliance }\end{array}$ & $(+)$ \\
\hline 3 & Total debt/Total assets & debt & $\begin{array}{l}\text { H3: The more debt a business has, the more likely does not } \\
\text { comply with CIT obligation }\end{array}$ & $(+)$ \\
\hline 4 & $\begin{array}{l}\text { Loss in the previous } \\
\text { year }\end{array}$ & loss & $\begin{array}{l}\text { H4: Enterprises with losses the previous year are more likely } \\
\text { to be non-compliant with CIT. }\end{array}$ & $(+)$ \\
\hline 5 & $\begin{array}{l}\text { Value of inventory/Total } \\
\text { assets }\end{array}$ & inv & $\begin{array}{l}\text { H5: There was a positive relationship between the ratio of } \\
\text { inventory to total assets and CIT non-compliance }\end{array}$ & $(+)$ \\
\hline 6 & $\begin{array}{l}\text { Accounts } \\
\text { receivable/Sales }\end{array}$ & ar & $\begin{array}{l}\text { H6: The more receivables a company has, the more likely } \\
\text { they are to fail to comply with CIT }\end{array}$ & $(+)$ \\
\hline 7 & $\begin{array}{l}\text { Accumulated } \\
\text { depreciation/Total } \\
\text { assets }\end{array}$ & depr & $\begin{array}{l}\text { H7: There was a positive relationship between the ratio } \\
\text { of accumulated depreciation to total assets and CIT non- } \\
\text { compliance. }\end{array}$ & $(+)$ \\
\hline 8 & $\begin{array}{l}\text { Declaration of CIT } \\
\text { payable/Profit before } \\
\text { tax }\end{array}$ & etr & $\begin{array}{l}\text { H8: The higher the effective tax rate is, the less likely it is to } \\
\text { fail to comply with CIT }\end{array}$ & $(-)$ \\
\hline 9 & Scale of business & size & $\begin{array}{l}\text { H9: The smaller the size of the enterprise is, the more likely it } \\
\text { is not to comply with high CIT. }\end{array}$ & $(-)$ \\
\hline 10 & $\begin{array}{l}\text { Fines related to } \\
\text { tax administrative } \\
\text { violations/tax amounts } \\
\text { payable in the period }\end{array}$ & pen & $\begin{array}{l}\text { H10: Enterprises with a lower ratio of tax fines over tax } \\
\text { amount payable in the period are more likely to fail to comply } \\
\text { with high CIT }\end{array}$ & $(-)$ \\
\hline 11 & Fields of business & field & $\begin{array}{l}\text { H11: Business lines impact the corporate income tax non- } \\
\text { compliance ability of companies. } \\
\text { Business lines impact the corporate income tax non- } \\
\text { compliance ability of companies. }\end{array}$ & \\
\hline
\end{tabular}


Table 3: Statistics describing variables

\begin{tabular}{|c|c|c|c|c|c|}
\hline \multicolumn{6}{|c|}{ (A) Quantitative variables } \\
\hline & (1) & (2) & (3) & (4) & (5) \\
\hline Variables & observation & mean & sd & $\min$ & $\max$ \\
\hline wc & 935 & 0,568 & 0,327 & 0,0127 & 1,949 \\
\hline sale & 935 & 2,092 & 2,444 & 0,00164 & 33,38 \\
\hline debt & 935 & 0,573 & 0,270 & 0 & 0,997 \\
\hline inv & 935 & 0,214 & 0,238 & 0 & 0,939 \\
\hline ar & 935 & 0,0676 & 0,115 & 0 & 1 \\
\hline depr & 935 & 0,550 & 1,209 & 0 & 17,28 \\
\hline etr & 935 & 0,171 & 0,170 & 0 & 2,6102 \\
\hline size & 935 & 7,038 & 0,586 & 5,246 & 8,878 \\
\hline pen & 935 & 0,188 & 0,195 & 0 & 2,368 \\
\hline \multicolumn{6}{|c|}{ (B) Qualitative variables } \\
\hline & $(1)$ & $(2)$ & (3) & & \\
\hline Variables & Value of identify & Frequency & Percentage & & \\
\hline \multirow[t]{2}{*}{ nct } & 0 & 293 & 31,34 & & \\
\hline & 1 & 642 & 68,66 & & \\
\hline \multirow[t]{2}{*}{ loss } & 0 & 727 & 77,75 & & \\
\hline & 1 & 208 & 22,25 & & \\
\hline \multirow[t]{3}{*}{ field } & 1 & 305 & 32,62 & & \\
\hline & 2 & 225 & 24,06 & & \\
\hline & 3 & 405 & 43,32 & & \\
\hline
\end{tabular}

\section{Research Results}

Table 3 presents an overview of the statistical summary of the variables in the proposed model.

Before performing Probit regression with the proposed model, the research conducted the Spearman correlation test to identify independent variables that are related to dependent variables in the data set. Spearman test results are presented in Table 4:

The results of Spearman correlation analysis show that there are eight independent variables correlated with the dependent variable (nct) at the significance level of 5\% and $10 \%$. They are wc, sale, debt, loss, ar, size, pen, and field. Therefore, these variables were used in Probit regression technique to determine the impact factors. The authors have performed Linktest, Hosmer and Lemeshow's test to confirm the suitability of the model. Then, we tested for multi-collinear and variance changes. The results showed that multi-collinearity in the model was negligible, but the model was affected by variance changes. Therefore, we used a robust estimation technique for this situation. Besides, we also tested for endogenous phenomena in the regression model with the variables regression method. The result showed that there was no evidence that endogenous phenomena exist in the research model. Hence, the original

Table 4: Correlating test results

\begin{tabular}{|l|c|c|}
\hline & \multicolumn{2}{|c|}{ Correlating test } \\
\hline & Spearman's rho & Prob > \\
\hline wc & $-0,1196$ & 0,0002 \\
\hline sale & 0,0575 & 0,0791 \\
\hline debt & 0,0664 & 0,0425 \\
\hline loss & 0,1562 & 0,0000 \\
\hline inv & $-0,0214$ & 0,5127 \\
\hline ar & $-0,0538$ & 0,0999 \\
\hline depr & 0,0146 & 0,6566 \\
\hline etr & $-0,0101$ & 0,7585 \\
\hline size & $-0,0904$ & 0,0056 \\
\hline pen & $-0,1383$ & 0,0000 \\
\hline field & 0,0734 & 0,0247 \\
\hline
\end{tabular}


Table 5: The result of Probit regression model by robust technique

\begin{tabular}{|c|c|}
\hline & nct \\
\hline \multirow[t]{2}{*}{ wc } & -0.763 \\
\hline & $(0.142)^{\star * *}$ \\
\hline \multirow[t]{2}{*}{ sale } & 0.062 \\
\hline & $(0.024)^{\star * *}$ \\
\hline \multirow[t]{2}{*}{ debt } & 0.501 \\
\hline & $(0.170)^{* * *}$ \\
\hline \multirow[t]{2}{*}{ loss } & 0.570 \\
\hline & $(0.117)^{\star * *}$ \\
\hline \multirow[t]{2}{*}{ ar } & -0.726 \\
\hline & $(0.386)^{*}$ \\
\hline \multirow[t]{2}{*}{ size } & -0.262 \\
\hline & $(0.083)^{* * *}$ \\
\hline \multirow[t]{2}{*}{ pen } & -0.926 \\
\hline & $(0.260)^{* * *}$ \\
\hline \multirow[t]{2}{*}{ 2bn.field } & 0.601 \\
\hline & $(0.124)^{\star * *}$ \\
\hline \multirow[t]{2}{*}{ 3.field } & 0.385 \\
\hline & $(0.105)^{* * *}$ \\
\hline \multirow[t]{2}{*}{ _cons } & 2.192 \\
\hline & $(0.621)^{\star * *}$ \\
\hline Số quan sát & 935 \\
\hline
\end{tabular}

Note: Standard errors in parentheses, ${ }^{* *} p<0.01 ;{ }^{* *} p<0.05$;

${ }^{*} p<0.1$

Probit regression model was better than the regression model with tool variables. Table 5 presented the resulting regression model:

According to the results, eight independent variables in the proposed model have a significant impact on the corporate income tax non-compliance of enterprises in Ho Chi Minh City. They are working capital/total assets; revenue/total assets; losses in the previous year; total debt/total assets; accounts receivable/sales; scale of business; fines related to tax administrative violations/tax amounts payable in the period; and fields of business.

\section{Conclusions and Policy Implications}

\subsection{Conclusions}

The results of the study reflected the current business environment and tax administration in Vietnam, which showed eight factors affecting corporate income tax noncompliance:
Working capital/Total assets: The results showed that this ratio had a negative relationship with corporate income tax non-compliance. When this index is high, the enterprise is in a stable financial situation, and the probability of corporate income tax non-compliance will be low. This result is consistent with the findings byNoor, Aziz, and Mastuki (2012), Spathis (2002), GIZ Sector Program Public Finance (2010).

Revenue/Total assets: This ratio has a positive relationship with tax non-compliance with enterprises. Our study has found that a high ratio of revenue to total assets means the revenue generated is big, which puts pressure on fulfilling the obligation to pay tax, thus, and leads to the possibility of corporate income tax non-compliance. This result is consistent with the comments from the discussion about building models and the result byNoor, Aziz, and Mastuki (2012).

Losses in the previous year: The study showed that loss had a positive relationship with the tax non-compliance of enterprises. Enterprises with losses in the previous year will take advantage of the regulations to carry losses forward over many following years, which leads to the possibility of corporate income tax non-compliance. Our result is consistent with Lou and Wang (2009) and the result of the discussions in Ho Chi Minh City.

Total debt/total assets: Our study showed that there was a positive relationship between the ratio of total debt to total assets and corporate income tax non-compliance. Businesses with more debt have the opportunity to take advantage of the tax shield, leading to the possibility of not complying with corporate income tax. This conclusion is consistent with the findings by $\mathrm{Vu}$ (2009); Lisowsky (2010); Noor, Aziz, and Mastuki (2012).

Accounts receivable/sales: The quantitative result was completely consistent with the actual statements from tax officials and enterprises when discussing this matter. This factor has a negative relationship with the possibility of corporate income tax non-compliance. Businesses with long-term receivable debts might take advantage of the provisioning to reduce income and not comply with corporate income tax. Our finding is consistent with the concepts proposed by Summers and Sweeney (1998), Schilit (2002).

The scale of business: Our study concluded that the smaller the firm size, the less it complies with corporate income tax due to the lack of knowledge in tax law and accounting. This result is consistent with the findings by Joulfaian (2000); Yusof, Ling, and Wah (2014).

Fines related to tax administrative violations/tax amounts payable in the period: This ratio has a negative relationship with corporate income tax non-compliance. If the amount of the penalty compared to the payable corporate income tax amount is low, the enterprise thinks that it is beneficial to pay the fine instead of paying tax. 
Therefore, companies easily commit fraud with tax law. This relationship is consistent with the confirmations of tax authorities and enterprises in discussions as well as the findings by Allingham and Sandmo (1972).

Fields of business: This result confirms the relationship between the fields of business and the corporate income tax non-compliance. Our findings are consistent with comments by tax authorities and enterprises and the results from Rice (1992); Chan and Mo (2000); Yusof, Ling, and Wah (2014).

\subsection{Policy Implications}

From the results, we proposed some suggestions on tax administration activities that contribute to reducing corporate income tax non-compliance of enterprises:

Firstly, our main recommendation is that tax officials pay attention to the relevant elements of the financial statement, while preparing for which businesses to audit.Eight factors drawn in this study can be selected as criteria for assessing compliance and risk classification of taxpayers.

Secondly, the loss from business activities was concluded to affect corporate income tax non-compliance, which is an opportunity for businesses to avoid paying tax. Therefore, the Government needs to adjust regulations on levels and time for loss-carrying in order to reduce tax non-compliance behaviors of companies.

Thirdly, fines for administrative violations also affect corporate income tax non-compliance. According to our study, the penalty did not have a strong impact on the sense of compliance based on the perception of taxpayers. Therefore, the regulations of tax administrative fines should be stricter, which can affect the attitude of taxpayers.

Fourthly, tax departments should make efforts to build an efficient system for managing invoices to control the declared revenue of companies. In Vietnam, it is necessary to have a strong network with Internet and modern technology.

Moreover, the Government should create conditions to strengthen the coordination between tax departments and other functional agencies such as commercial banks, customs authorities, police agencies, etc., to control the economic transactions of businesses in the market which can help tax officials handle and prevent fraud behaviors such as illegal trading of invoices, use of illegal invoices, hiding revenue, and declaring false expenses.

\section{References}

Abdixhiku, L. (2013). Determinants of Business Tax Evasion in Transition Economies. Doctoral Thesis. Business School, Staffordshire University, Stoke-on-Trent, England. https://core. ac.uk/reader/43608704
Alabede, J. O., Ariffin, Z. B. Z., \& Idris, K. M. (2011). Determinants of Tax Compliance Behaviour: A Proposed Model for Nigeria. International Research Journal of Finance and Economics, 78, 121-136.

Allingham, M. G., \& Sandmo, A. (1972). Income Tax Evasion: A Theoretical Analysis. Journal of Public Economics, 1(3-4), 323-338. https://doi.org/10.1016/0047-2727(72)90010-2.

Alm, J. (1991). A Perspective on the Experimental Analysis of Taxpayer Reporting. The Accounting Review, 66(3), 577-593. https://www.jstor.org/stable/247810.

Awan, A. G., \& Hannan, A. (2014). The Determinants of Tax Evasion in Pakistan - A Case Study of Southern Punjab. International Journal of Development and Economic Sustainability, 2(4), 50-69. Available at: http://www.eajournals.org/wp-content/ uploads/The-Determinants-of-Tax-Evasion-in-Pakistan-ACase-Study-of-Southern-Punjab.pdf

Becker, G. S. (1968). Crime and Punishment: An Economic Approach. Journal of Political Economy, 76, 169-217. https:// www.nber.org/chapters/c3625.pdf

Braithwaite, V. (2009). Defiance in Taxation and Governance: Resisting and Dismissing Authority in a Democracy. Cheltenham, UK: Edward Elgar.

Brautigam, D., Odd-Helge, F., \& Moore, M. (eds.) (2008). Taxation and state-building in developing countries. New York, NY: Cambridge University Press.

Bui, N. T. (2017). Factors affecting corporate income tax compliance behavior - Experimental Study in HCMC. Journal of Science Hue University, 126, 77-88. [Vienamese]

Chan, K. H., \& Mo, P. L. L. (2000). Tax Holidays and Tax Noncompliance: An Empirical Study of Corporate Tax Audits in China's Developing Economy. The Accounting Review, 75(4), 469-484. https://www.jstor.org/stable/248625.

Chipeta, C. (2002). The Second Economy and Tax Yield in Malawi. Research Paper No. 113. Nairobi, Kenya: African Economic Research Consortium. Available at: https://aercafrica.org/wpcontent/uploads/2018/07/RP113.pdf.

Cressey, D. R. (1953). Other People's Money: A Study of the Social Psychology of Embezzlement. New York, NY: Free Press.

Devos, K. (2014). Factors Influencing Individual Taxpayer Compliance Behaviour. Dordrecht, Netherlands: Springer Science-Business Media.

Duong, C. M. (2011). How Market Mispricing Affects Investor Behaviour, Corporate Investment and Real Earnings Management: The UK Evidence. Doctoral Thesis. University of Kent. Canterbury, England. Available at: https://ethos.bl.uk/ OrderDetails.do?uin=uk.bl.ethos.594266

Fishlow, A., \& Friedman, J. (1994). Tax evasion, inflation and stabilization. Journal of Development Economics, 43(1), 105123. https://doi.org/10.1016/0304-3878(94)90025-6.

Frank, M. M., Lynch, L. J., \& Rego, S. O. (2009). Tax Reporting Aggressiveness and Its Relation to Aggressive Financial 
Reporting. The Accounting Review, 84(2), 467-496. https:// www.jstor.org/stable/27802660.

Giz Sector Programme Public Finance (2010). Addressing Tax Evasion and Tax Avoidance in Developing Countries. Deutsche Gesellschaft Fur Internationale Zusammenarbeit. Available at: https://www.taxcompact.net/sites/default/files/resources/201012-ITC-Addressing-Tax-Evasion-and-Avoidance.pdf

Hanlon, M., Mills, L. F. \& Slemrod, J. (2005). An Empirical Examination of Corporate Tax Noncompliance. In: Taxing Corporate Income in the 21st Century (pp. 171-210). New York, NY: Cambridge University Press. https://doi.org/10.1017/ CBO9780511510823.014

Joulfaian, D. (2000). Corporate Income Tax Evasion and Managerial Preferences. The Review of Economics and Statistics, 82(4), 698-701. https://www.jstor.org/stable/2646664.

Kamdar, N. (1997). Corporate Income Tax Compliance: A Time Series Analysis. Atlantic Economic Journal, 25, 37-49. https:// doi.org/10.1007/BF02298475.

Kinsey, K. A. (1986). Theories and Models of Tax Cheating. Criminal Justice Abstracts, 18, 403-425.

Kirchler, E., Muehlbacher, S., Kastlunger, B., \& Wahl, I. (2007). Why Pay Taxes? A Review of Tax Compliance Decisions. International Studies Program Working Paper 07-30. Atlanta, GA: Andrew Young School of Policy Studies, Georgia State University. Available at: https://icepp.gsu.edu/files/2015/03/ ispwp0730.pdf

Le, X. T., \& Nguyen, D. C. (2013). Identifying tax fraud acts. Financial Magazine, 9, 97-112. Retrieved from: http:// tapchitaichinh.vn/nghien-cuu-trao-doi/nghien-cuu-dieu-tra/ nhan-dien-cac-hanh-vi-gian-lan-thue-64692.html

Lewis, A. (1982). The Social Psychology of Taxation. British Journal of Social Psychology, 21(2), 151-158. https://doi. org/10.1111/j.2044-8309.1982.tb00523.x.

Lieberman, E. (2002). Taxation Data as Indicators of State-Society Relations: Possibilities and Pitfalls in Cross-National Research. Studies of Comparative International Development, 36(1), 89115. https://doi.org/10.1007/BF02686334.

Lisowsky, P. (2010). Seeking Shelter: Empirically Modeling Tax Shelters Using Financial Statement Information. The Accounting Review, 85(5), 1693-1720. https://www.jstor.org/ stable/27895889.

Loebbecke, J. K., Eining, M. M. \& Willingham, J. J. (1989). Auditors' Experience with Material Irregularities: Frequency, Nature, \& Detectability. Auditing: A Journal of Practice \& Theory, 9, 1-28.

Lou, Y. I. \& Wang, M. L. (2009). Fraud Risk Factor of the Fraud Triangle Assessing the Likelihood of Fraudulent Financial Reporting. Journal of Business and Economics Research, 7(2), 61-78. https://doi.org/10.19030/jber.v7i2.2262.

Mills, L. F. (1996). Corporate Tax Compliance and Financial Reporting. National Tax Journal, 49(3), 421-435. https://www. jstor.org/stable/41789215.
Ministry of Finance (2016). State Budget Settlement Report. Hanoi, Vietnam.

Mo, P. L. L. (2003). Tax avoidance and anti-avoidance measures in major developing economies. Westport, CT.: Praeger.

Murray, M. N. (1995). Sales Tax Compliance and Audit Selection. National Tax Journal, 48(4), 515-530. https://ideas.repec.org/a/ ntj/journl/v48y1995i4p515-30.html

Nguyen, D. T. \& Nguyen, T. M. T. (2009). Market Research. Ho Chi Minh City: Lao Dong Publishing House. [Vietnamese]

Nguyen, D. T. (2011). Methods of scientific research in business. Ho Chi Minh City: Lao Dong Publishing House. [Vietnamese]

Nguyen, H. H. (2019). Impact of Direct Tax and Indirect Tax on Economic Growth in Vietnam. Journal of Asian Finance, Economics and Business, 6(4), 129-137. https://doi. org/10.13106/jafeb.2019.vol6.no4.129.

Nguyen, M. H., \& Nguyen, H. Q. (2012). Factors affecting tax compliance behavior of private enterprises - considering the aspect of timely tax payment. Journal of Banking Technology, 80, 23-34.

Nguyen, T. T. D., Pham, T. M. L., Le, T. T., Truong, T. H. L., \& Tran, M. D. (2020). Determinants Influencing Tax Compliance: The Case of Vietnam. Journal of Asian Finance, Economics and Business, 7(2), 65-73. https://doi.org/10.13106/jafeb.2020. vol7.no2.65.

Noor, R. M., Aziz, A. A., \& Mastuki, N. A. (2012). Tax Fraud Indicators. Malaysian Accounting Review, 11, 43-57. http:// dx.doi.org/10.24191/mar.v11i1.217

Noor, R. M., Jamaludin, N. E., Omar, N., \& Aziz, R. A. (2013). Measuring Tax Gap in the Service Industry. Proceedings of 3rd Global Accounting. Finance and Economics Conference. Rydges Melbourne, Australia.

Oh, K.W., \& Ki, E. S. (2020). Effect of Tax-Related Information on Pre-Tax Income Forecast and Value Relevance. Journal of Asian Finance, Economics and Business, 7(1), 81-90. https:// doi.org/10.13106/jafeb.2020.vol7.no1.81.

Organization for Economic Cooperation and Development (2004). Compliance Risk Management: Managing and Improving Tax Compliance. Paris, France: Centre for Tax Policy and Administration. https://www.oecd.org/tax/ administration/33818656.pdf

Pashev, K. (2005). Tax Compliance of Small Business in Transition Economies: Lessons from Bulgaria. International Studies Program Working Paper 05-10. Atlanta, GA: Andrew Young School of Policy Studies, Georgia State University. http:// dx.doi.org/10.2139/ssrn.717041.

Persons, O. S. (1995). Using Financial Statement Data to Identify Factors Associated with Fraudulent Financial Reporting. Journal of Applied Business Research, 11(3), 38-46. https://doi. org/10.19030/jabr.v11i3.5858.

Rice, E. (1992). The Corporate Tax Gap: Evidence on Tax Compliance by Small Corporations. In: Slemrod, J. (Ed.), Why 
People Pay Taxes: Tax Compliance and Enforcement. Ann Arbor, MI: University of Michigan.

Salehi, M., Khazaei, S., \& Tarighi, H. (2019). Tax Avoidance and Corporate Risk: Evidence from a Market Facing Economic Sanction Country. Journal of Asian Finance, Economics and Business, 6(4), 45-52. https://doi.org/10.13106/jafeb.2019. vol6.no4.45.

Sapiei, N. S., Kasipillai, J., \& Eze, U. C. (2014). Determinants of Tax Compliance Behaviour of Corporate Taxpayers in Malaysia. Journal of Tax Research, 12(2), 383-409. http:// www5.austlii.edu.au/au/journals/eJlTaxR/2014/17.pdf

Schilit, H. (2002). Financial Shenanigans, New York, NY: McGraw-Hill.

Schmolders, G. (1959). Fiscal Psychology: A New Branch of Public Finance. National Tax Journal, 12(4), 340-345. https:// www.jstor.org/stable/41790780.

Singh, V. (2003). Tax Compliance and Ethical Decision-Making: A Malaysian Perspective. Kuala Lumpur, Malaysia: Pearson Malaysia Sdn. Bhd.

Skousen, C. J., Smith, K. R., \& Wright, C. J. (2009). Detecting and Predicting Financial Statement Fraud: The Effectiveness of the Fraud Triangle and Sas No. 99. Advances in Financial Economics, 13, 53-81. http://dx.doi.org/10.2139/ssrn.1295494.

Song, Y., \& Yarbrough, T. E. (1978). Tax Ethics and Taxpayer Attitudes: A Survey. Public Administration Review, 38(5), 442452. https://www.jstor.org/stable/975503.

Spathis, C. T. (2002). Detecting False Financial Statements Using Published Data: Some Evidence from Greece. Managerial Auditing Journal, 17(4), 179-191. https://doi. org/10.1108/02686900210424321.

Spicer, M. W. (1974). A Behavioral Model of Income Tax Evasion. Ph.D. Thesis. Columbus, OH: Ohio State University.
Summers, S. L. \& Sweeney, J. T. (1998). Fraudulently Misstated Financial Statements and Insider Trading: An Empirical Analysis. The Accounting Review, 73(1), 131-146. https:// www.jstor.org/stable/248345.

Tan, L. M., \& Sawyer, A. J. (2003). A Synopsis of Taxpayer Compliance Studies: Overseas Vis-À-Vis New Zealand. New Zealand Journal of Taxation Law and Policy, 9, 431-454.

Vogel, J. (1974). Taxation and Public Opinion in Sweden: An Interpretation of Recent Survey Data. National Tax Journal, 27(4), 499-513. https://www.jstor.org/stable/41861983.

$\mathrm{Vu}$, H. D. (2009). Using ratios on financial statements to detect tax deviations. Journal of Economic Development, 12, 56-61.

Yahyapour, Y., Boroujeni, A. G. \& Kheradyar, S. (2015). The Influence of Factors on Corporate Tax Evasion: Evidence from the Firms of Guilan Province. International Journal of Review in Life Sciences, 5, 567-574.

Yalama, G. O., \& Gumus, E. (2013). Determinants of Tax Evasion Behavior: Empirical Evidence from Survey Data. International Business and Management, 6(2), 15-23. http://dx.doi. org/10.3968/j.ibm.1923842820130602.1085

Yusof, N. A. M., Ling, L. M., \& Wah, Y. B. (2014). Tax Noncompliance among SMCs in Malaysia: Tax Audit Evidence. Applied Accounting Research, 15(2), 215-234. https://pdfs.semanticscholar.org/f95b/ e348ac8aa2b82865418708288a5dd83e6d86.pdf

Zainal, A. M. Y., Hasseldine, J., \& Paton, D. (2010). An Analysis of Tax Non-Compliance Behaviour of Small and Medium-Sized Corporations in Malaysia. In: K. Datt, T.-N., B., and Bain, K (Ed.), International Tax Administration: Building Bridges. Sydney, Auatralia: $\mathrm{CCH}$ Australia Limited. 